\title{
"Show, don't tell": Using visual mapping to chart emergent thinking in self-reflexive research
}

\section{Tanya van der Walt}

Drama \& Performance Studies Programme, School of Arts, University of KwaZulu-Natal, Durban, South Africa tanyalvdw@gmail.com

https://orcid.org/0000-0002-0754-6669

(Received: 15 September 2019; accepted: 17 January 2020)

\begin{abstract}
This paper explores the articulation and representation of ways in which visual mapping can be an important tool for the designing, conducting, interpreting, and writing phases of a research project. It uses examples from my own work to show the ways in which visual mapping can be used to develop and clarify the thinking, and to provide a form of visual validation of the insights gained, in self-reflexive research. Visual mapping can operate as a meaning-making process - helping the researcher to make sense of their thinking through visual means while also helping the reader to understand the researcher's thinking processes better-through a series of diagrams that trace the development of thoughts and ideas. Visual mapping is one method self-reflexive researchers can use to demonstrate what Mishler called "the visibility of the work" (1990, p. 429), and to make plain the ways in which our thinking developed, and the connections we make between theory, data, and analysis. By making our thinking process visible, we allow our reader to "see the study and the links and leaps made" (Pinnegar \& Hamilton, 2010, p. 150).
\end{abstract}

Keywords: visual mapping, self-reflexive, thinking, meta-cognition

\section{Introduction}

As a drama lecturer and theatre-maker, I often advise students and actors to "show, don't tell" in their performance, exhorting them to demonstrate their feelings and ideas rather than just talking about them. In my own research project entitled, Co-Directing, Co-Creating, Collaborating: A Self-Reflexive Study of My Collaborative Theatre-Making Practice (van der Walt, 2018), I followed my own advice, and made extensive use of visual mapping both to develop my thinking, and to make that thinking visible in the body of the written work itself. In so doing, I engaged in a metacognitive, self-reflexive process of thinking about my thinking that made visible the multilayered process of coming to know through an examination of my own practice. 


\section{Reflection, reflexivity, self-study}

In discussing the nature and intent of the research agenda, Eliot Eisner observed:

What we think it means to do research has to do with our conception of meaning, our view of cognition, and our beliefs about the forms of consciousness that we are willing to say advance human understanding — an aim, I take it, that defines the primary mission of research. $(1997$, p. 5)

In my study, I sought to understand how I enact my collaborative theatre-making practice to elucidate the selves I bring to that practice (who am I?), and the ways in which that practice enables a process of teaching and learning. In so doing, I engaged in a process whereby I sited my self at the centre of my research. By placing myself and my own practice under the microscope of my inquiry, I engaged with both reflection and reflexivity - two sides of the same coin. Gillie Bolton provided useful definitions of both reflection and reflexivity:

Reflection is learning and development through examining what we think happened on any occasion, and how we think others perceived the event and us, opening our practice to scrutiny by others, and studying data and texts from a wider sphere.

Reflexivity is finding strategies to question our own attitudes, thought processes, values, assumptions, prejudices and habitual actions, to strive to understand our complex roles in relation to others. ... To be reflexive involves thinking from within experiences. ... Reflexivity is making elements of the self strange; focusing close attention upon one's own actions, thoughts, feelings, values, identity, and their effect upon others, situations, and professional and social structures. (2010, pp. 13-14)

Thus, my research was, by definition, both reflective and self-reflexive; I "bend and turn back in [my] continual quest to move forward from not knowing to knowing" (Pithouse-Morgan, Mitchell, \& Pillay, 2014, p. 1). My study examined my self-in-action, in order to generate knowledge that is rooted in my practice, and which is generated by that practice.

The chosen research approach for this study was self-study of practice, which we can understand "in relation to teaching and researching practice in order to better understand: oneself; teaching; learning; and, the development of knowledge about these" (Loughran, 2004 , p. 9). Self-study of practice (also commonly referred to as "self-study") is a methodology that arises from teacher education and is premised on the idea that, as teachers and practitioners, "we know more than we can tell" (Polanyi, 1967, p. 4). Thus, self-study of practice falls within the realm of self-reflexive methodologies of research that allow the researcher to examine their own practice in order to learn more about that practice and, in some way, improve it. Sandra Weber pointed out that

self-study is often a multipurpose endeavour that simultaneously involves research, teaching, learning, and evaluation. The design of any self-study usually centres on key questions such as: What am I really doing/teaching? What influences my practice? 
How does my teaching affect others? How might I improve what I do? How might I view things differently? How can I make a difference to others? (2014, p. 8)

Self-study of practice involves the excavation of the self-in-action, and a deeper understanding of the enacted practice that is created by the self-in-action. As Alan Ovens and Tim Fletcher explained: "What stands self-study apart from other forms of practitioner inquiry is the simultaneous focus on understanding self as it enacts practice" (2014, p. 6). Self-study of practice uncovers and examines practice in order to examine both the self and the practice itself.

In the body of literature that discusses this methodological approach, there is considerable stress on the idea that while the term "self-study" defines the intention of the inquiry, it does not dictate the ways in which the researcher chooses to gather their data, or how they go about analysing it (Loughran, 2004; Samaras, 2011). Rather, it is considered characteristic of self-study of practice that it engages with a range of, largely qualitative, methods (LaBoskey, 2004; Loughran, 2004; Pinnegar \& Hamilton, 2010; Samaras, 2011) that include memory work, personal history narratives, arts-based methods, critical friend inquiry (Samaras, 2011), and living educational theory (Whitehead \& McNiff, 2006) among others. In self-study, the researcher has a wide range of choices of how to generate their data, while the intention of the inquiry as stance (LaBoskey, 2004) is more narrowly defined. Vicki Kubler LaBoskey pointed out that self-study researchers

utilize methods that will rely upon and give access to evidence of student learning that will capture the complexity and particularity of what we do and of ways in which what we do result in, or not, the reframed thinking and practice of our students and ourselves. (2004, p. 839)

One of the key methods I used to develop and clarify my thinking throughout my selfreflexive study was the spider diagram, concept map (Butler-Kisber \& Poldma, 2010), or mind-map (Buzan, 2010). In creating a series of diagrams that traced the development of my thoughts and ideas through the years of the growth of the study, I found a way to visually connect the many ideas and insights I had gained.

\section{Mapping my emergent thinking}

In discussing this kind of visual mapping, Toni Krasnic explained that

visual mapping is known by many other names, most notable mind mapping®, but also concept mapping, flow-charting, visual thinking, spider diagramming, memory mapping, semantic mapping, and thought webbing. (2010, p. 1)

The purpose of this kind of visual mapping is to create a graphic means of representing complex thought processes; it is a way of organising thoughts into maps that will allow you to draw connections and conclusions from your thinking in ways that may not have been possible until they were represented visually. As Butler-Kisber and Poldma explained: 
Concept maps allow the researcher to step outside the constraints of linear thinking and to engage in, and encourage the messy and nonlinear work of, the brain, and in so doing, to tease out ideas and connections in the data that might otherwise remain implicit. It is when these implicit thoughts become apparent that the analysis can be pushed to a deeper level. (2010, p. 9)

Thus, visual mapping operates as a meaning-making process that helps the researcher to make sense of their own thinking through visual means. Visual mapping can also help the reader to better understand the researcher's thinking processes. For this reason, I decided to include my diagrams (some are mind-maps, some are spider diagrams, and some are rhizomatic concept maps) in the body of my writing as a way to evidence and make transparent the development of my thinking. I see these diagrams as artefacts of thinking that allow me to organise and synthesise my ideas. Anastasia Samaras observed that "the artifact, like a metaphor, stands for, represents, and expresses the student's research interests" (2010, p. 724). As such, I used visual mapping to "demonstrate how experiential ways of knowing and understanding ... are a means of making tacit ideas explicit and make new insights possible for both the researcher and the research audience" (Butler-Kisber \& Poldma, 2010, p. 2). In some cases, the diagrams were reproduced as "tidied up" figures within the text but, in most cases, I simply included photographs or scanned copies of the original freehand diagrams made in my research notebooks in order to preserve the authenticity of my thinking in that particular moment.

In order to give some idea of the various ways in which I used visual mapping, I now go on to discuss the seven different levels of mapping that are present in my study.

\section{Mapping the emergent structure of my thesis}

I began my use of visual mapping in my study with the following four artefacts of thinking to illustrate the development of my thought process regarding how to go about structuring the work. These were included in a short chapter that I called "A Methodological Parenthesis" (van der Walt, 2018), in which I detailed the ways in which I intended to use visual mapping throughout the thesis. That chapter also allowed me to show the reader exactly how and why the structural logic of my study had developed. 


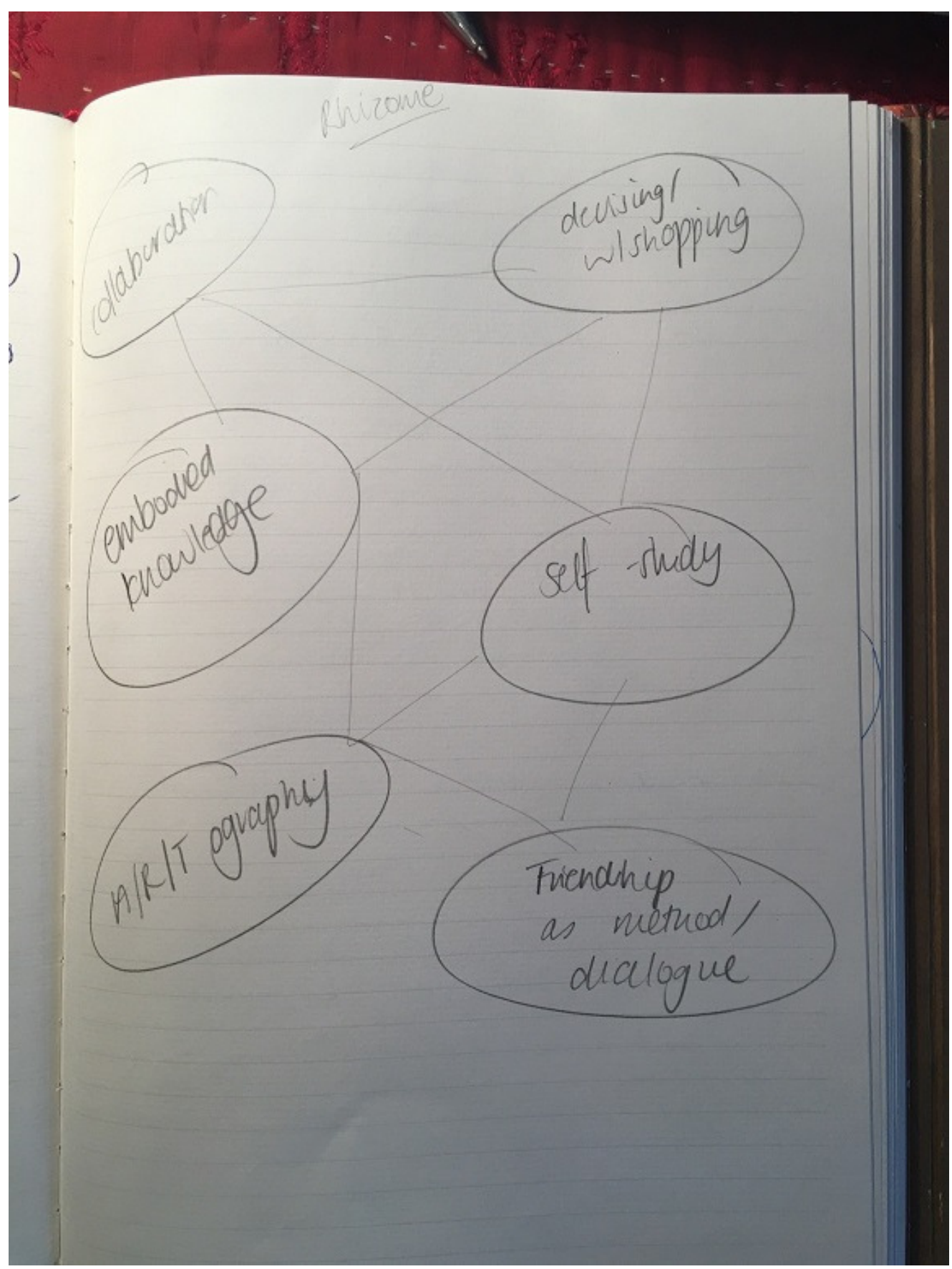

Figure 1: Early rhizomatic concept map for the project

The rhizomatic concept map (Figure 1)—which moves (zigzagging from top left to bottom right) through the concepts of collaboration, devising/workshopping, embodied knowledge, self-study, a/r/tography, and friendship as method/dialogue-details some of my early thinking in terms of the concepts and areas of scholarship that my study would have to engage with. The diagram attempted to find ways to connect the disparate concepts and areas of research that were floating around my head, and to find a way to map a path through these different aspects of the study. Some of these ideas, such as collaboration, devising/workshopping, friendship, and dialogue, served as springboards to further explorations and new ideas whilst others, such as a/r/tography and embodied knowledge, did 
not have a great impact on the direction of the study. Instead, as my thinking developed, I was able to construct a visual map of my initial structure for the study (Figure 2).

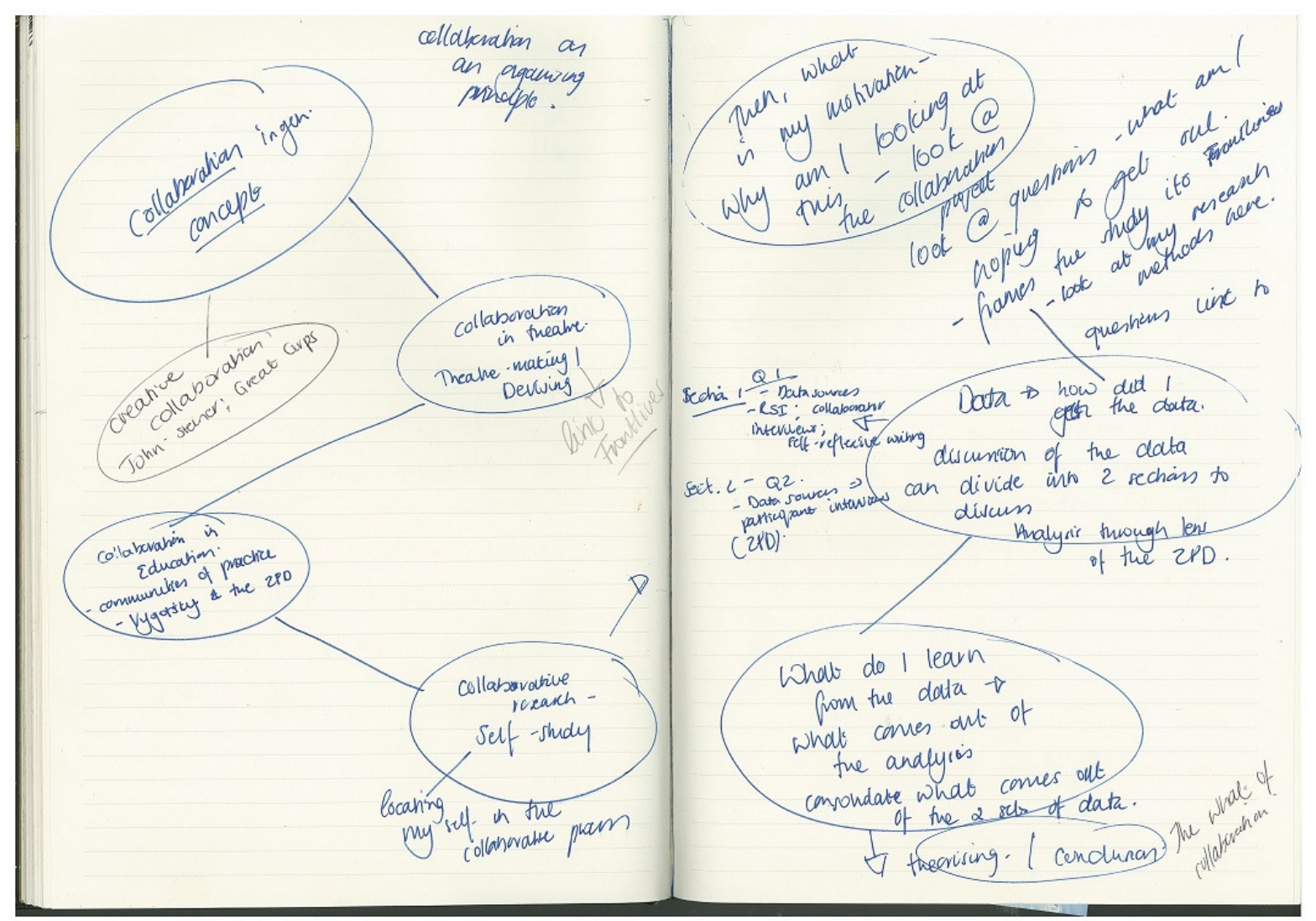

Figure 2: Visual map of my study in my research notebook

This visual map formed the impetus for my thinking about how to approach the actual structuring of the study. I used it to delineate all the different areas and aspects that the work needed to cover, including collaboration as a general concept, collaboration in theatre, collaboration in education, and collaborative research, as well as my key research questions and what I could learn from my data. I then used this map to decide on a rough order of chapters as I began the writing process.

I am a member of what Vera John-Steiner (2000) called a community of thought in the form of a self-reflexive research support group based at the University of KwaZulu-Natal, School of Education. At one of our monthly meetings, I presented the visual map diagram in a neater format for feedback from the group (Figure 3). 


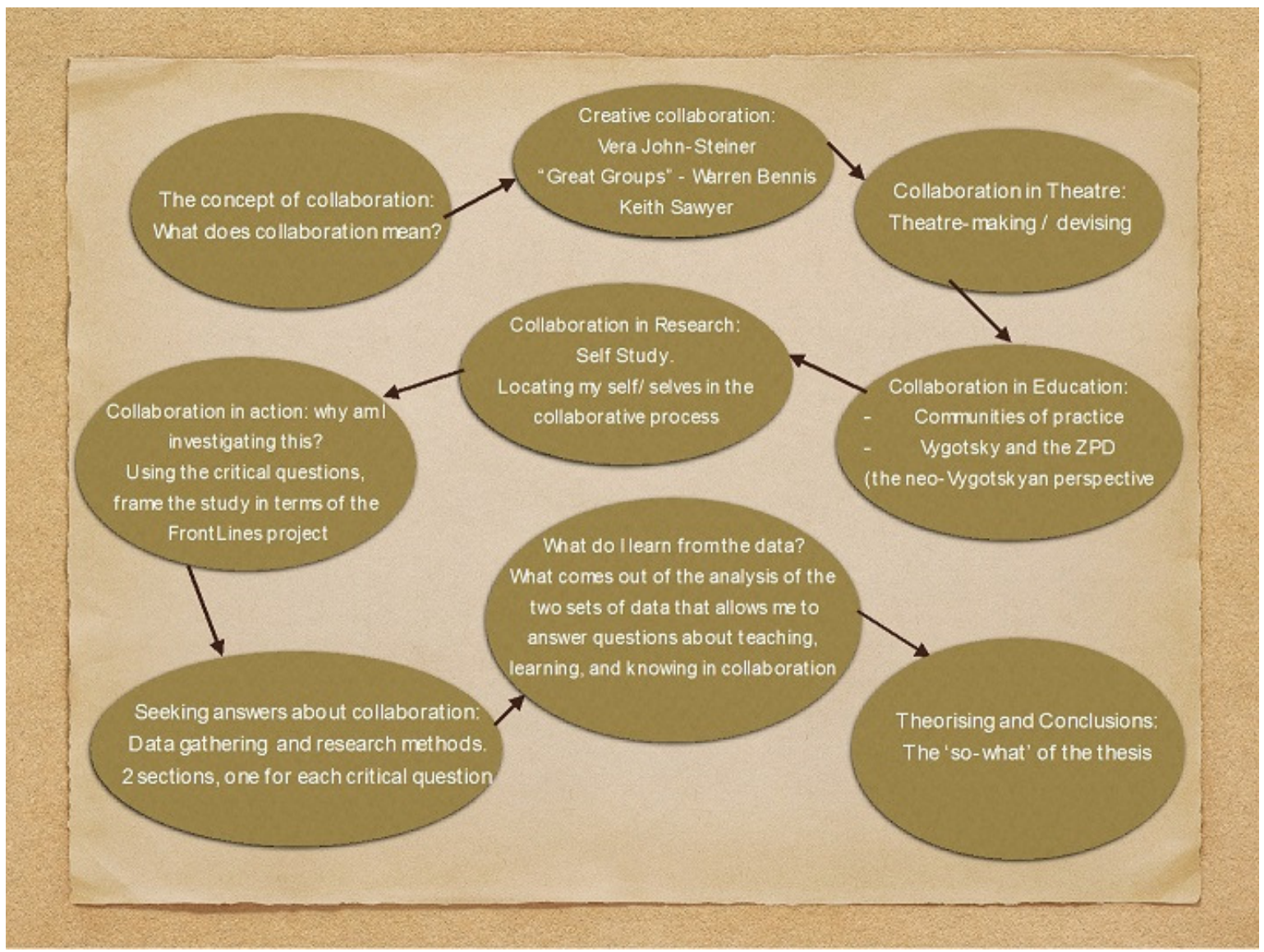

Figure 3: Visual map diagram presented to the self-reflexive research group

The feedback from the presentation of this diagram was instrumental in helping me to find a way through the writing of my study and the structuring of my central argument. Later in the writing process, however, I reached an impasse; I realised that the rather conventional structure that I had developed in the image in Figure 3 was not working. As I wrestled with the complex problem of how to connect "excerpts plus literature plus data" (Pinnegar \& Hamilton, 2010, p. 150), I radically rethought the structure of the study and developed a new visual map (Figure 4). 


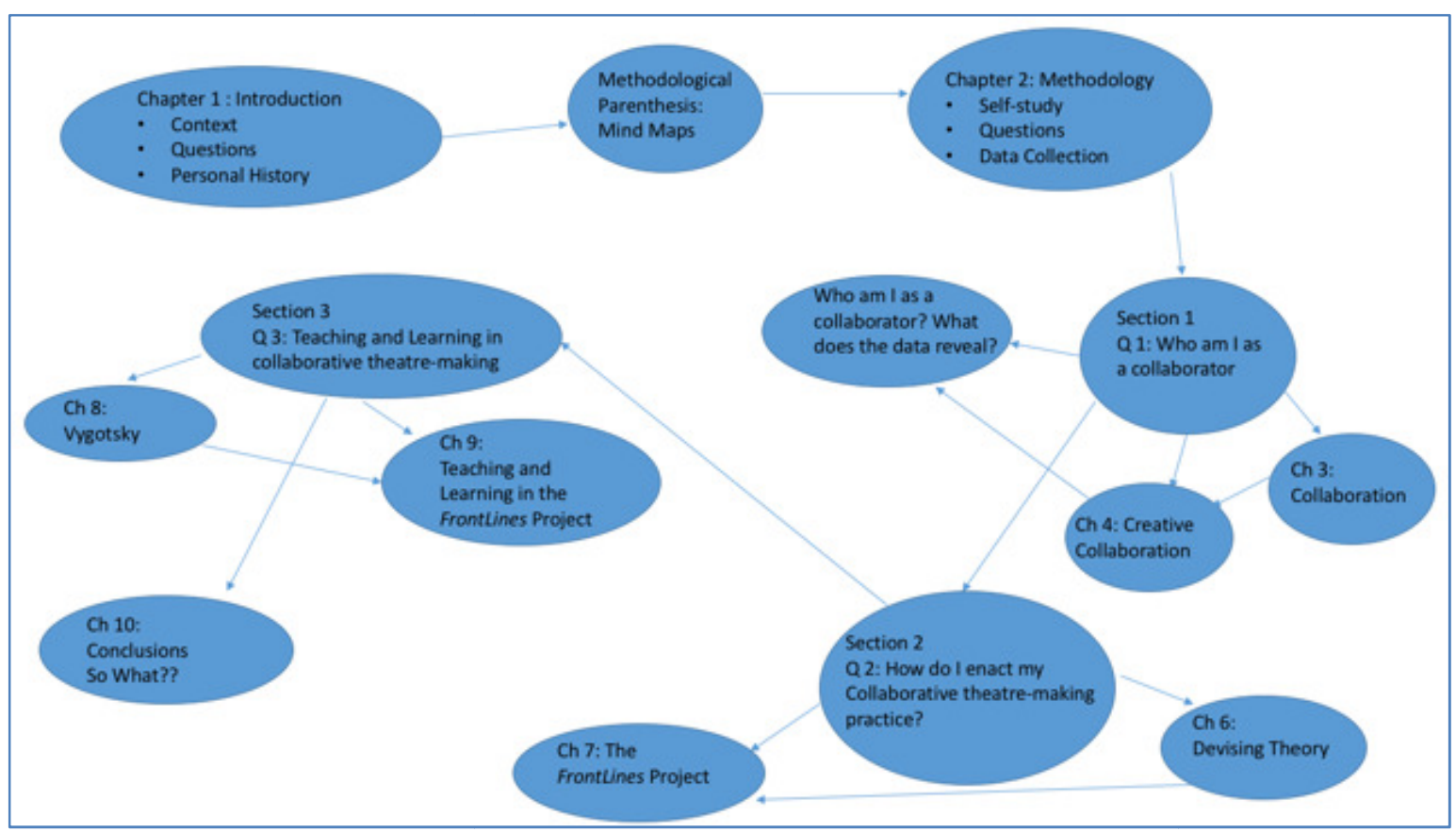

Figure 4: The rethought structure of the study

This map served to guide me through the writing journey of the thesis, helping me to "clarify these evolving ideas, enabling a return to the textual analysis and writing with new understandings" (Butler-Kisber \& Poldma, 2010, p. 9).

\section{Mapping my way through methodology}

In setting out to answer my research questions, I chose to engage with what are considered the five key characteristics of self-study of practice research, which are discussed widely in the work of Loughran (2004), LaBoskey (2004), Pinnegar and Hamilton (2010). However, I chose to structure my study around what my critical friend and collaborator, Tamar Meskin, and I termed our "Idiot's Guide to Self-Study" (Meskin \& van der Walt, 2018), which was a synthesis of the ideas of LaBoskey (2004) and Samaras (2011) regarding these key characteristics of self-study of practice. When I began to think about how these five key characteristics could be applied to my own study, I was able to develop an artefact of 
thinking (Figure 5).

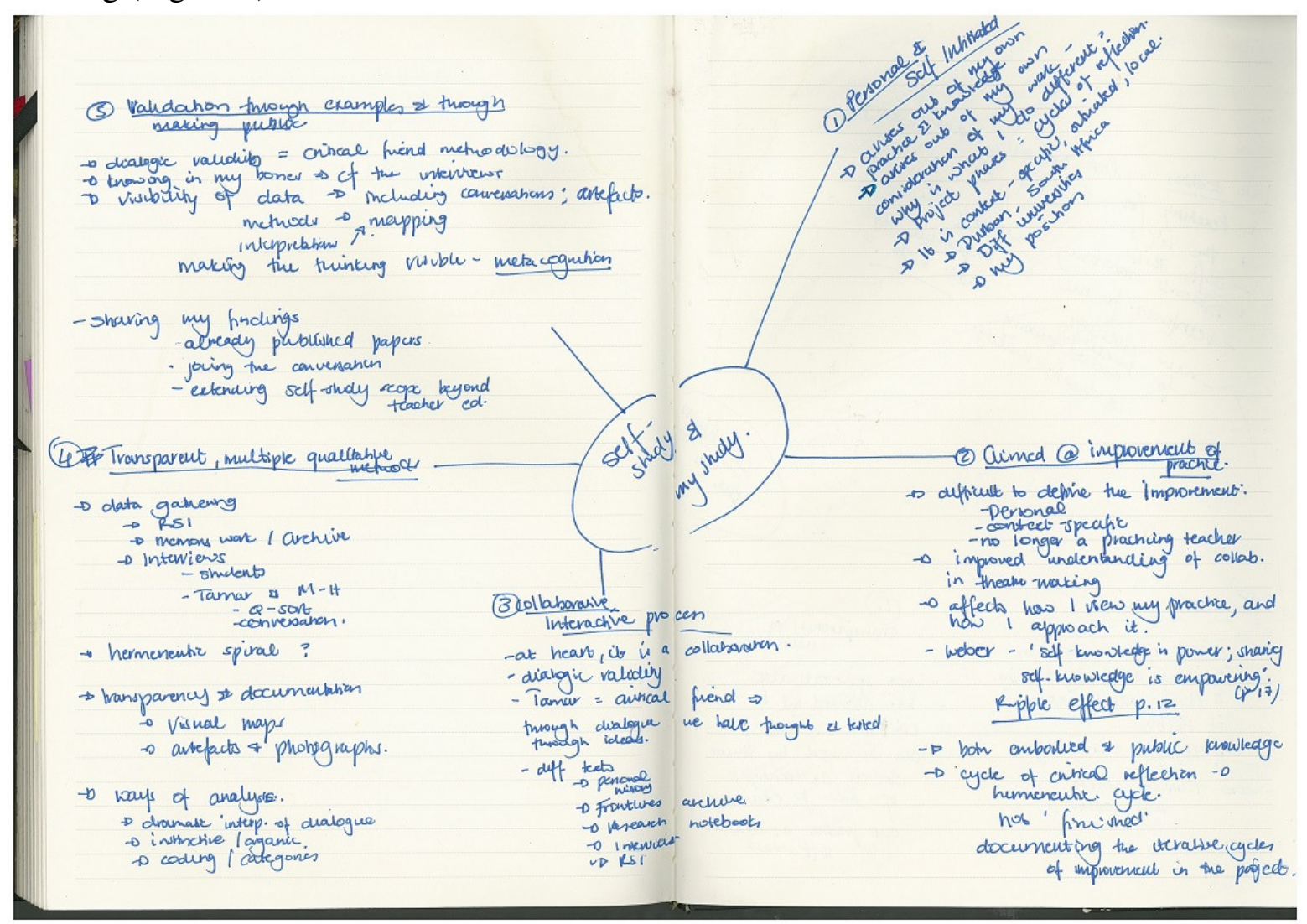

Figure 5: Self-study and my study

The five characteristics identified were that self-study of practice research is personal and self-initiated; aimed at improvement of practice; a collaborative, interactive process; uses transparent, multiple qualitative methods; and is validated through examples and through making the work public (Meskin \& van der Walt, 2018). The connections I drew between these characteristics and my own research project then formed the basis of my discussion of methodology and allowed me to clearly map, for myself, all the ways in which my study connected to and embodied the key characteristics of self-study of practice research.

\section{Mapping my way through complex concepts}

In seeking to understand my collaborative theatre-making practice, my study demanded an engagement with a number of conceptual frameworks, each of which allowed me to grapple with my research questions. These concepts included devising, collaboration, creative collaboration, and Vygotskian thought. In each case, I was able to map my thinking about the concepts in order to draw connections, see new pathways, and create new understandings.

Mapping these concepts allowed me to distil a large amount of reading and thinking about each concept into a single map that then allowed to me identify key characteristics and critical ideas. These maps therefore underpinned and informed my discussion of each concept. 


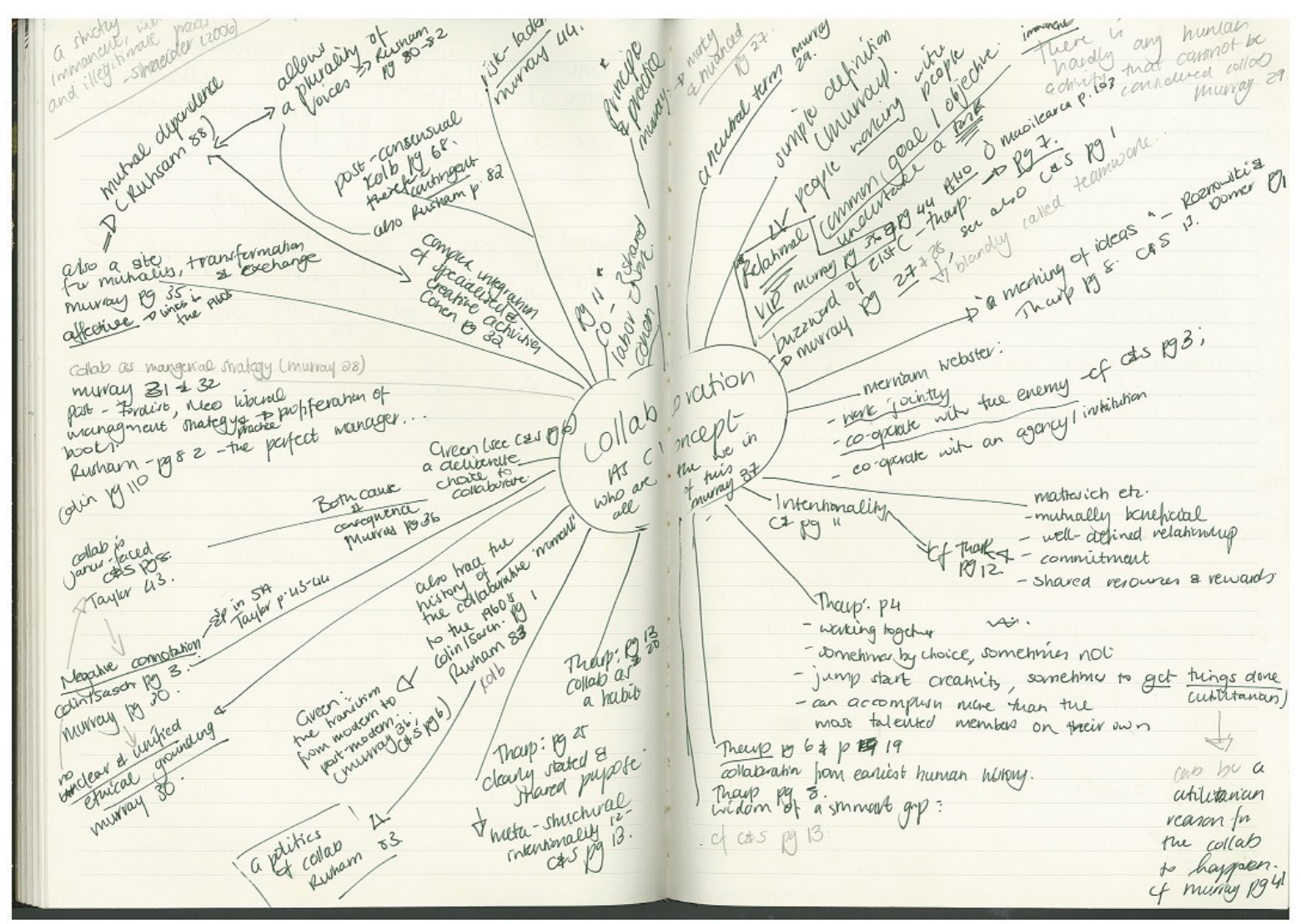

Figure 6: Visual map of the concept of collaboration

The map in Figure 6 is one of the best examples of this kind of visual thinking, and was the first of the large maps I created. When I began to write my chapter on collaboration, which was one of the first complete chapters that I attempted, I struggled to find my way through all the information I had gathered. To help clarify my thoughts, I sat down and produced this visual map to try to distil what I had read and learned into a form that I could use to elucidate the concept of collaboration. Through this process, I was able to identify the following twelve characteristics of collaboration:

- Collaboration is relational and allows for a plurality of voices.

- Collaboration is not always by choice, but it almost always involves a deliberate choice to collaborate.

- Collaboration is intentional.

- Collaboration involves shared thinking.

- The sum of collaboration is greater than its parts.

- Collaboration involves risk.

- Collaboration is immanent, and can be traced from earliest human history.

- Contemporary models of collaboration have their roots in the social ferment of the 1960s.

- Collaboration in the 21 st century is an integral part of neoliberal management strategies and practice.

- In the 21 st century, collaboration is post-consensual and contingent. 
- Collaboration can have strongly negative connotations.

- Collaboration is a neutral term, but it is not a neutral practice-it is Janus-faced. (van der Walt, 2018)

Once I had identified these characteristics, I explored them in greater detail, which allowed me to draw a conceptual framework for collaboration.

It was after completing this map that I realised that I would be able to include the maps that I was making, instinctively and organically, into the body of my writing as a way of demonstrating to my reader how I had come to the understandings that I was presenting. Therefore, visual mapping allowed me to navigate my way through complex concepts in a way that made them clear and understandable — both to me and to the reader.

\section{Mapping my way through complex ideas}

In order to reach these understandings of difficult concepts, I also had to grapple with complex ideas-largely through reading the work of numerous thinkers in each area of study. In many cases, the works of these thinkers were so difficult to wrestle with that I, once again, turned to visual mapping as a way to make sense of each of their ideas.

The best example of this was in the building of my understanding of the concept of creative collaboration. Most of the literature in this field is written by cognitive psychologists, an area in which I have little expertise. There were a number of key texts that I had to grapple with in depth in order to create a clear conceptual framework for creative collaboration. I therefore created a visual map for each of the works that I read, which allowed me to make connections within the work of each author and also to extrapolate and distil key ideas that carried across from author to author (see Figure 7 and Figure 8 for two examples of these visual maps). 


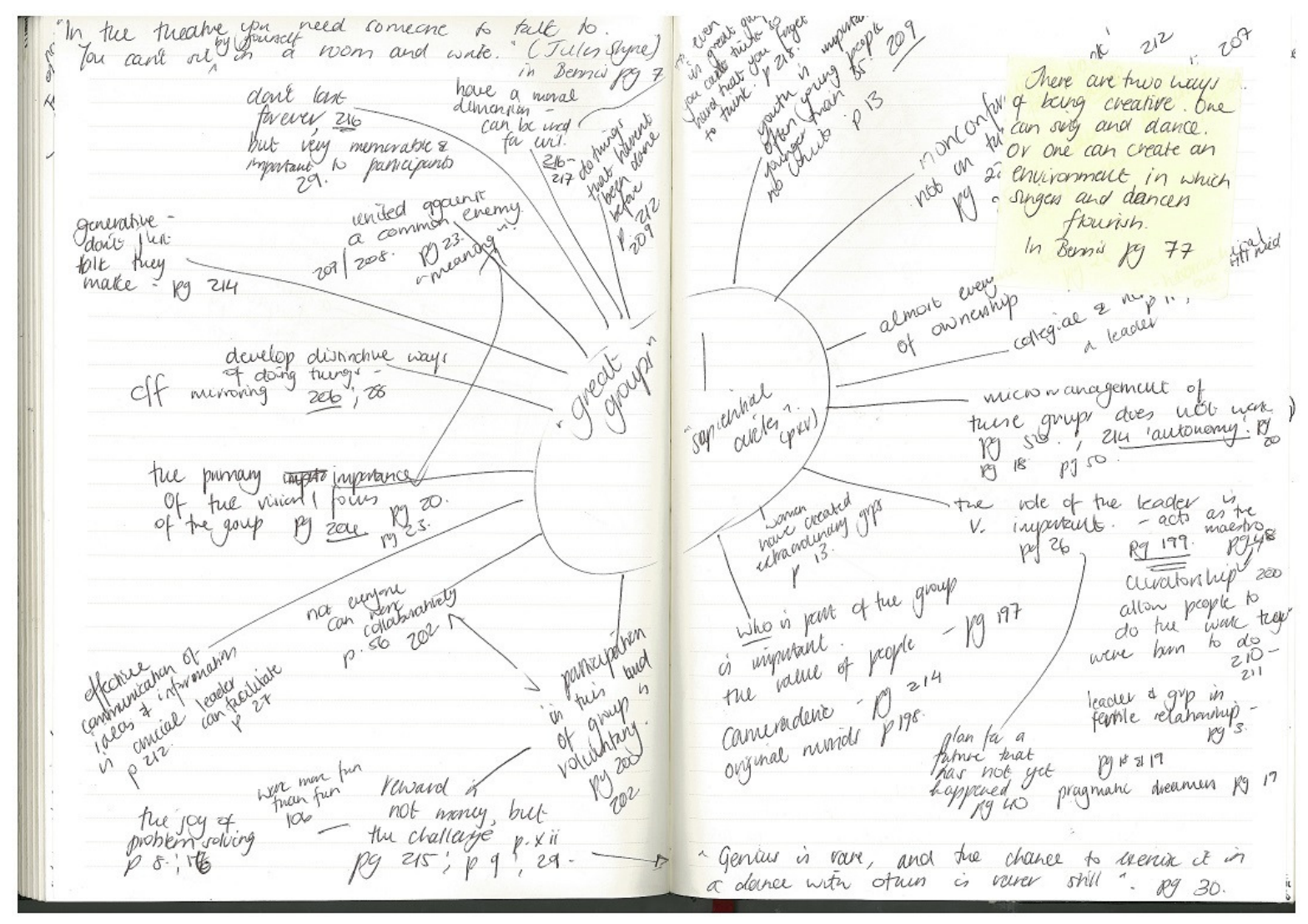

Figure 7: A visual map of Bennis and Biederman's work on "Great Groups" (1997)

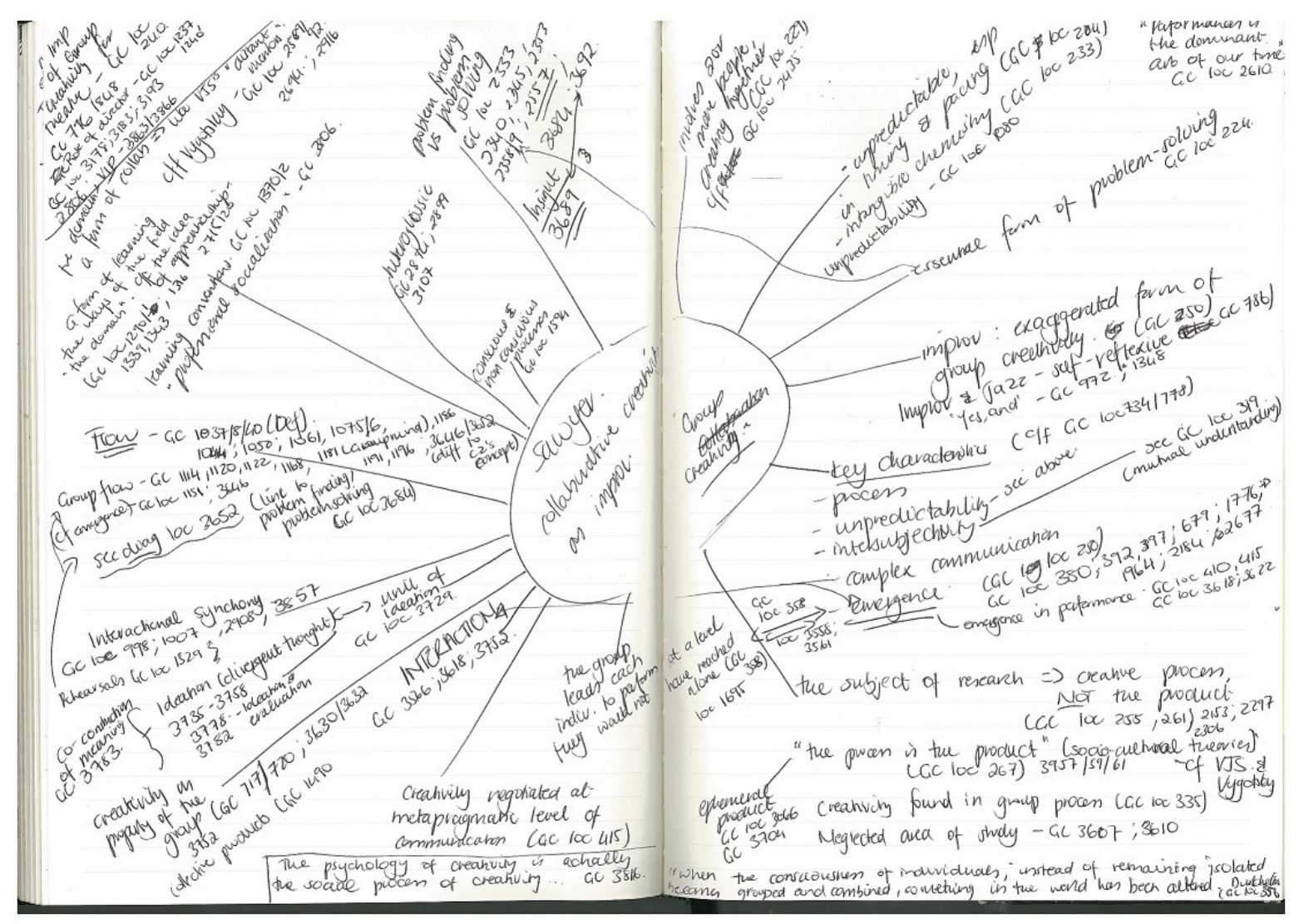

Figure 8: A visual map of Keith Sawyer's Group Creativity: Music, Theatre, Collaboration (2003) 
Once I had examined and mapped the work of each author, I was able to build a composite visual map of the concept of creative collaboration, one that brought together and encompassed the ideas of all of the various authors (Figure 9).

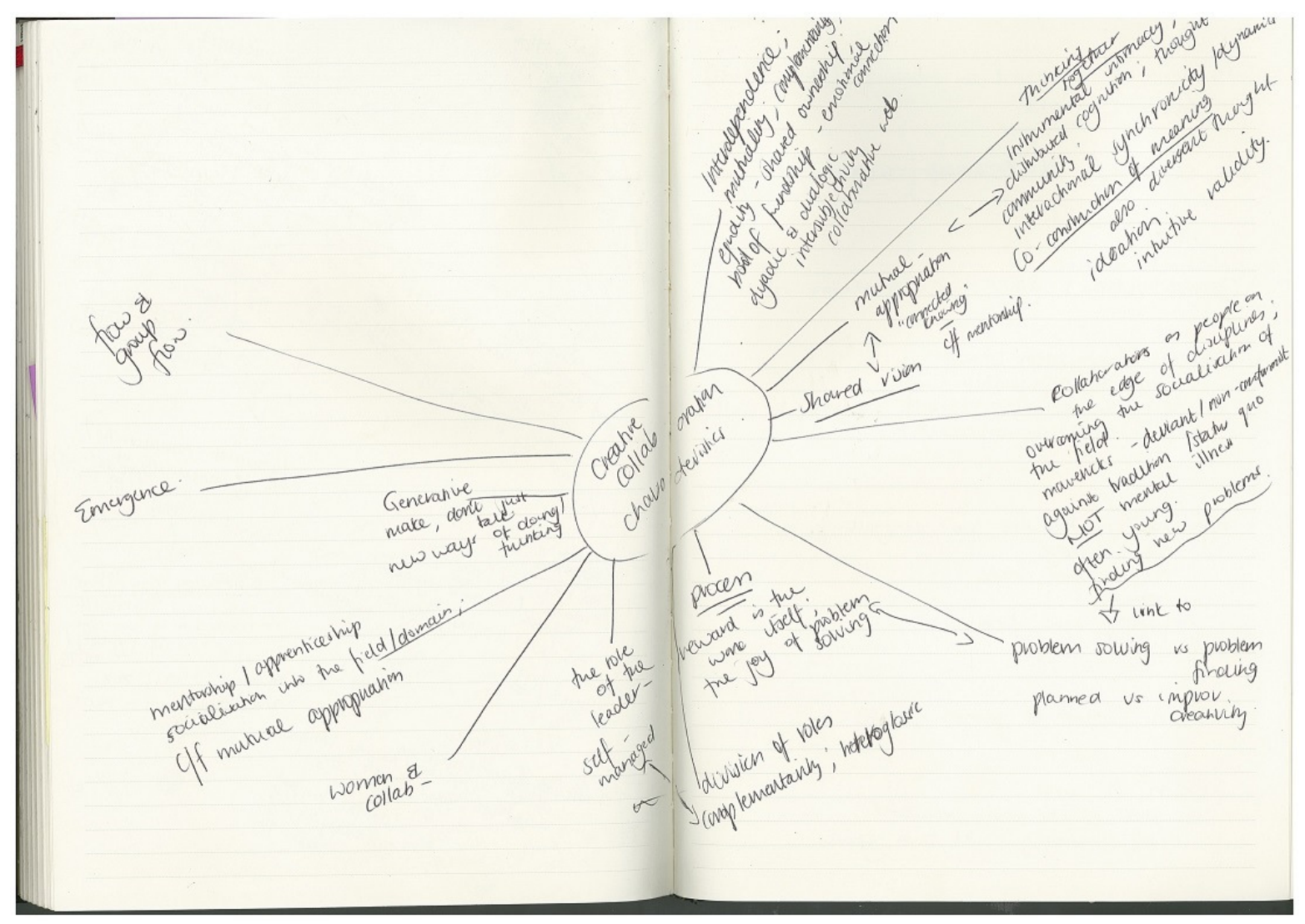

Figure 9: An artefact of thinking about the characteristics of creative collaboration

This map allowed me to identify key characteristics of creative collaboration including interdependence, thinking together, co-construction of meaning, emergence, generativity, mutual appropriation, shared vision, problem solving versus problem finding, and flow, which I could then expand on in my discussion.

\section{Mapping my way through the data}

The data used in my study was largely generated through informal interviews with a range of participants. ${ }^{1}$ In analysing the data, I was primarily looking for "manageable themes, patterns, trends and relationships" (Mouton, 2001, p. 108). Initially, I read the transcripts as I would any play text, seeking to find the subtext and the hidden meanings imbedded in the dialogue. I approached this task with an open mind, working in an instinctive and organic manner.

Once I had done this and gained a broad overview, I looked at the data again and again-each time searching for a different set of codes or categories. In each of these steps, I went on to build visual maps of the different themes that arose out of the coding of the data, finding my way into the connections and relationships between different aspects of the data. Thus, my

$1 \quad$ Participants in my study included my co-directors and selected students involved in the devised theatre project that formed the central case study of my inquiry. 
handling of the data was a recursive, hermeneutic process of "making meaning of [my] data" (Samaras, 2011, p. 198).

As an example of this, in the first section of my study, I used a process of both open and axial coding, to crystallise (Richardson \& St. Pierre, 2005) my response to the question of who I am as a collaborator. Once I had identified points of convergence between the theoretical and conceptual understandings of collaboration that I had already developed and the data, I was able to generate a visual map (Figure 10).

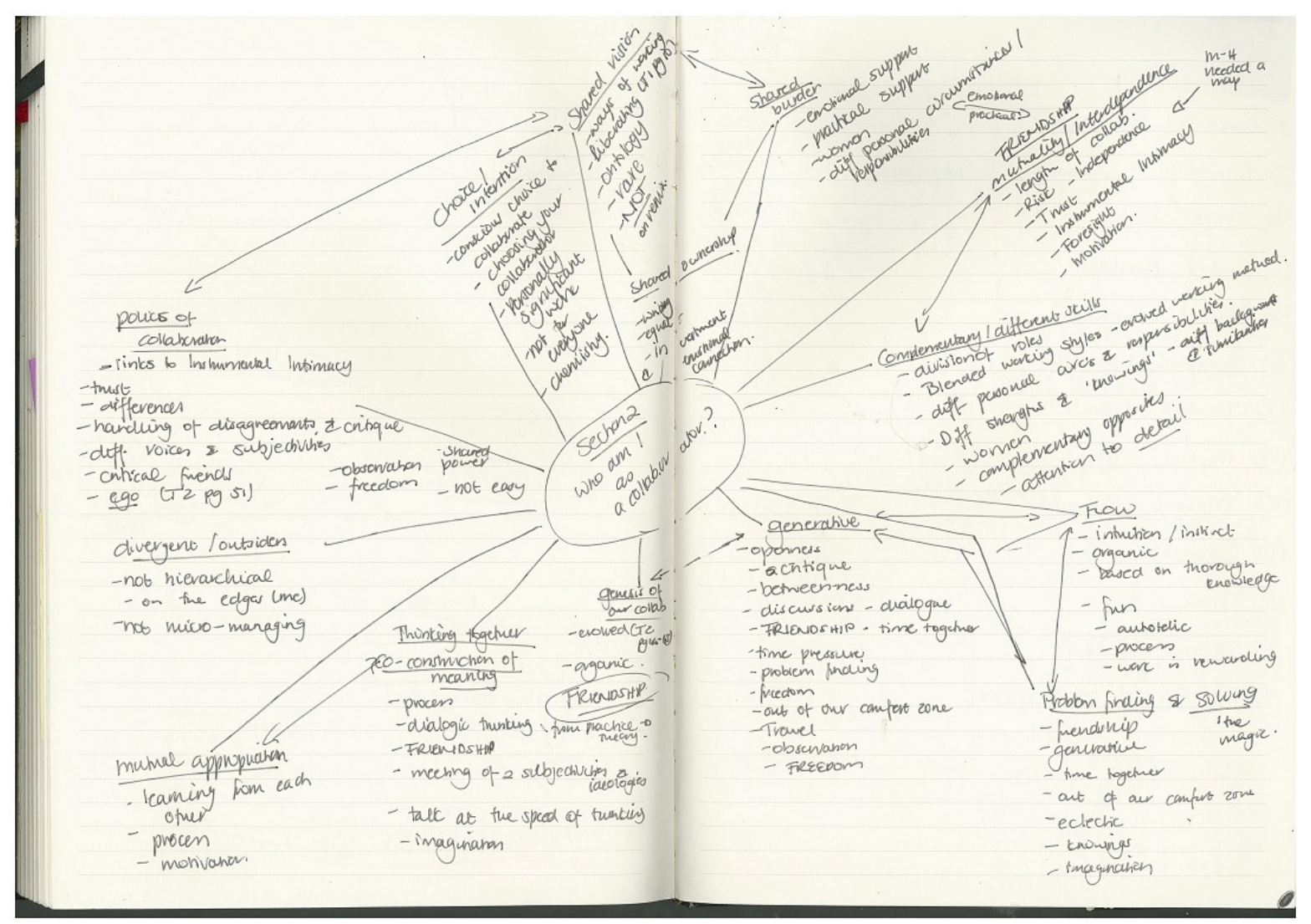

Figure 10: Visual map of the categories arising out of my coding of the data

In this way, I was able to identify key categories that arose out of the data and that would reveal more about my self and the way in which I collaborate. These included choice/intention, shared vision and shared burden, shared ownership, mutuality and interdependence, complementary/different skills, flow, problem finding and solving, generativity, genesis of collaboration, thinking together, mutual appropriation, divergence, and the politics of collaboration.

\section{Mapping my self through the data}

As seen above, one of the key critical questions of my study was, "Who am I as a collaborator?" I felt that a part of attempting to answer this question lay in what the data could teach me about my self (or selves) as a collaborator. In order to gain an even deeper understanding of this, I needed to look closely at the ways in which my participants answered some of my probing questions. I had asked each of them to characterise me as a collaborator, 
and to describe what it is like to collaborate with me. Each of them answered at length, with what I felt to be a high degree of honesty, by providing me with a fairly long list of descriptive phrases and adjectives that they would use to describe who I am as a collaborator. I created a very rough list of these, and then used them to create a visual map (Figure 11) in which I tried to group the words and phrases thematically.

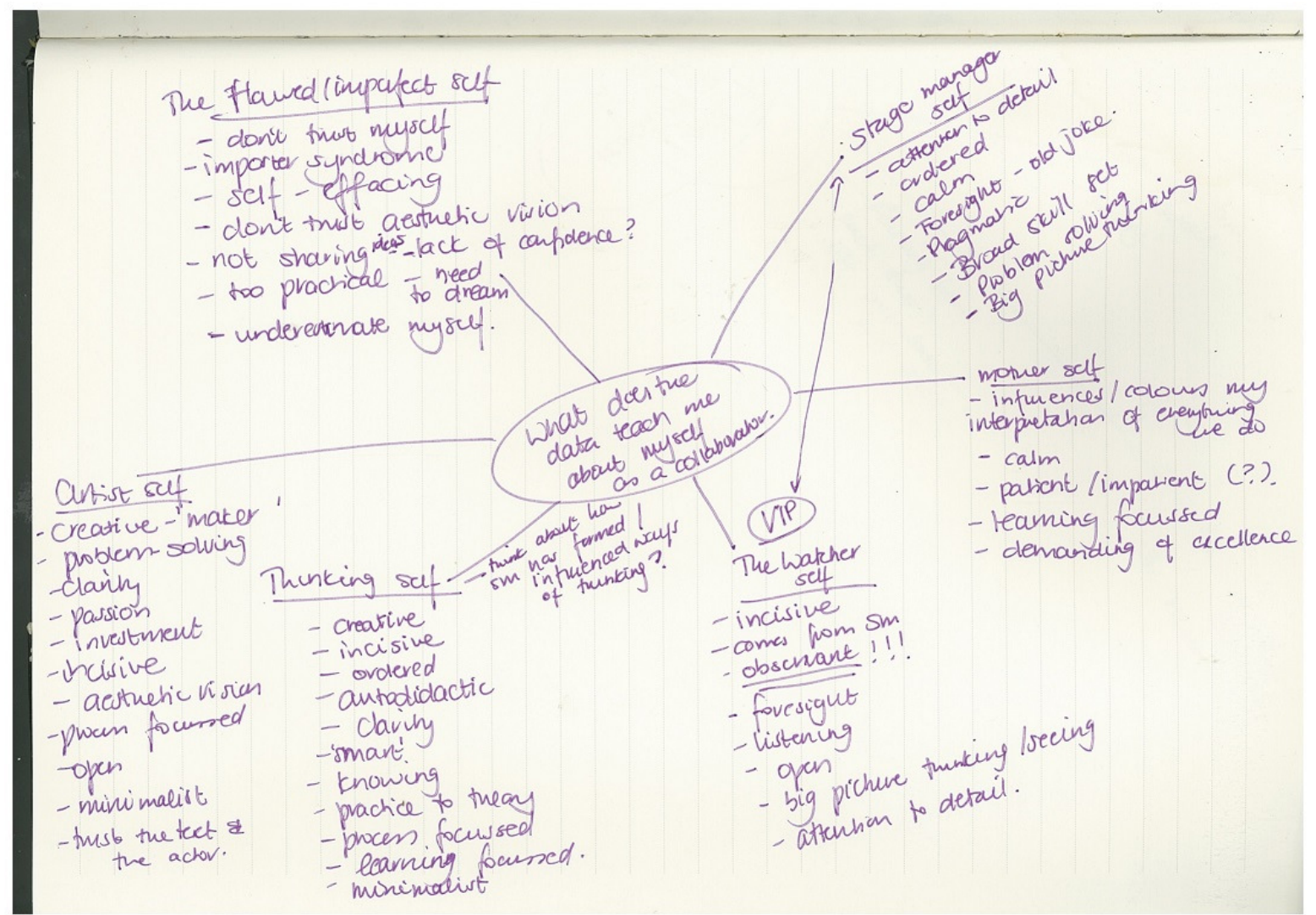

Figure 11: Visual map of the ways in which my respondents described me as a collaborator

What this revealed to me was that I can conceive of a series of selves that are me as a collaborator: the stage manager self, the mother self, the watcher self, the thinking self, the artist self, and the flawed self. For each of these selves, using the list of adjectives and descriptive phrases that my data had generated, I was then able to form word clouds to encompass each of the aspects of who I am as a collaborator (see, for example, Figure 12). 


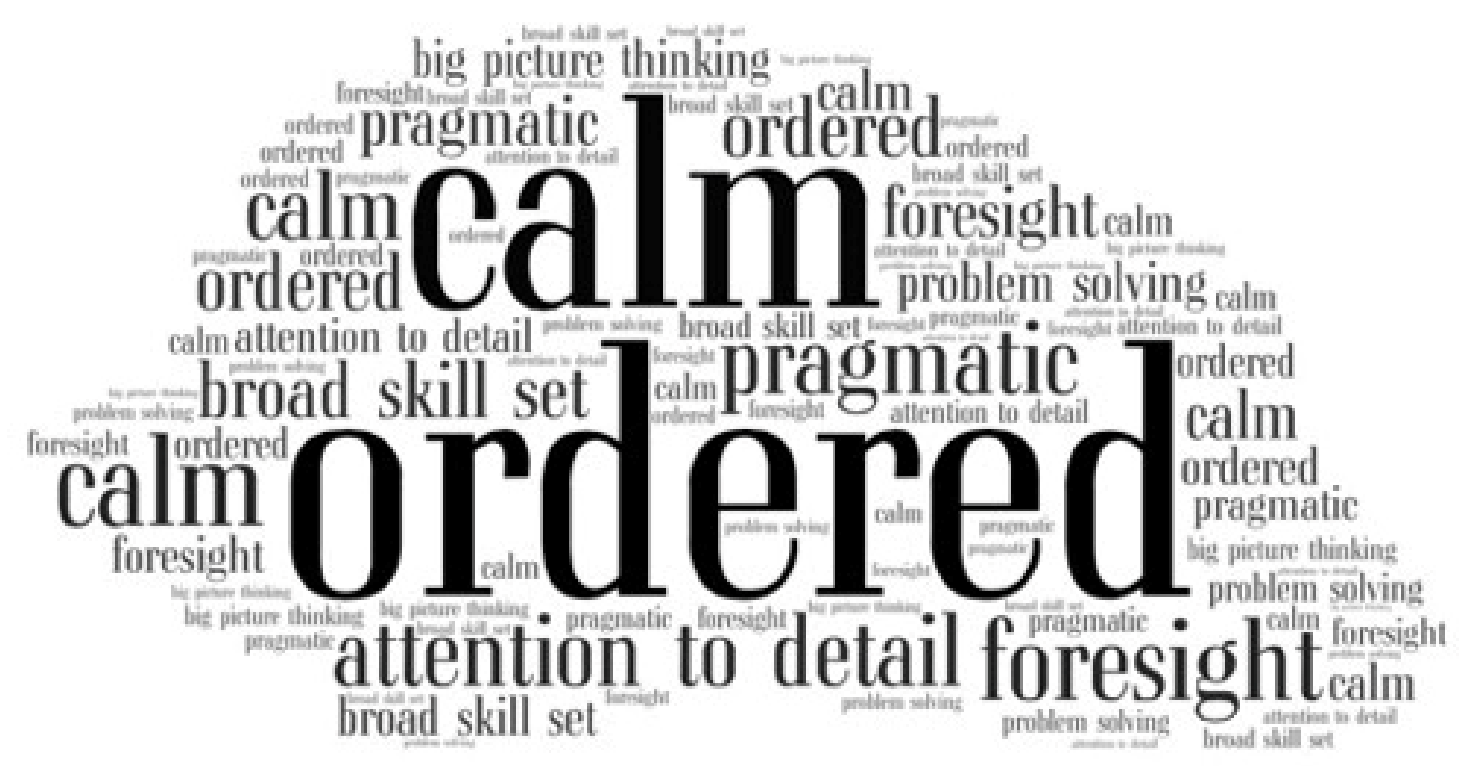

Figure 12: Word cloud that describes my stage manager self

Mapping the teaching and learning

Having come to a more nuanced understanding of the workings of my collaborative theatremaking practice, and to a clearer sense of who I am as a collaborator, I was able to move on to a consideration of the educational effect of my practice. Similar to the way in which I handled the data to answer my earlier research question, I first worked instinctively and organically, simply looking for places where any of my participants attempted to articulate either what they were trying to teach in the project, or what they had learned, or both. Once I had noted these, I was able to go back and code the data by trying to understand the different types of teaching and learning that were taking place. However, when I tried to create a mindmap or spider diagram of these, I was, for the first time in my study, stymied. I struggled to find a way into the data, and struggled to represent it visually in a way that made sense. In the end, I found that a grid-style arrangement worked better for this section, as can be seen in Figure 13. 


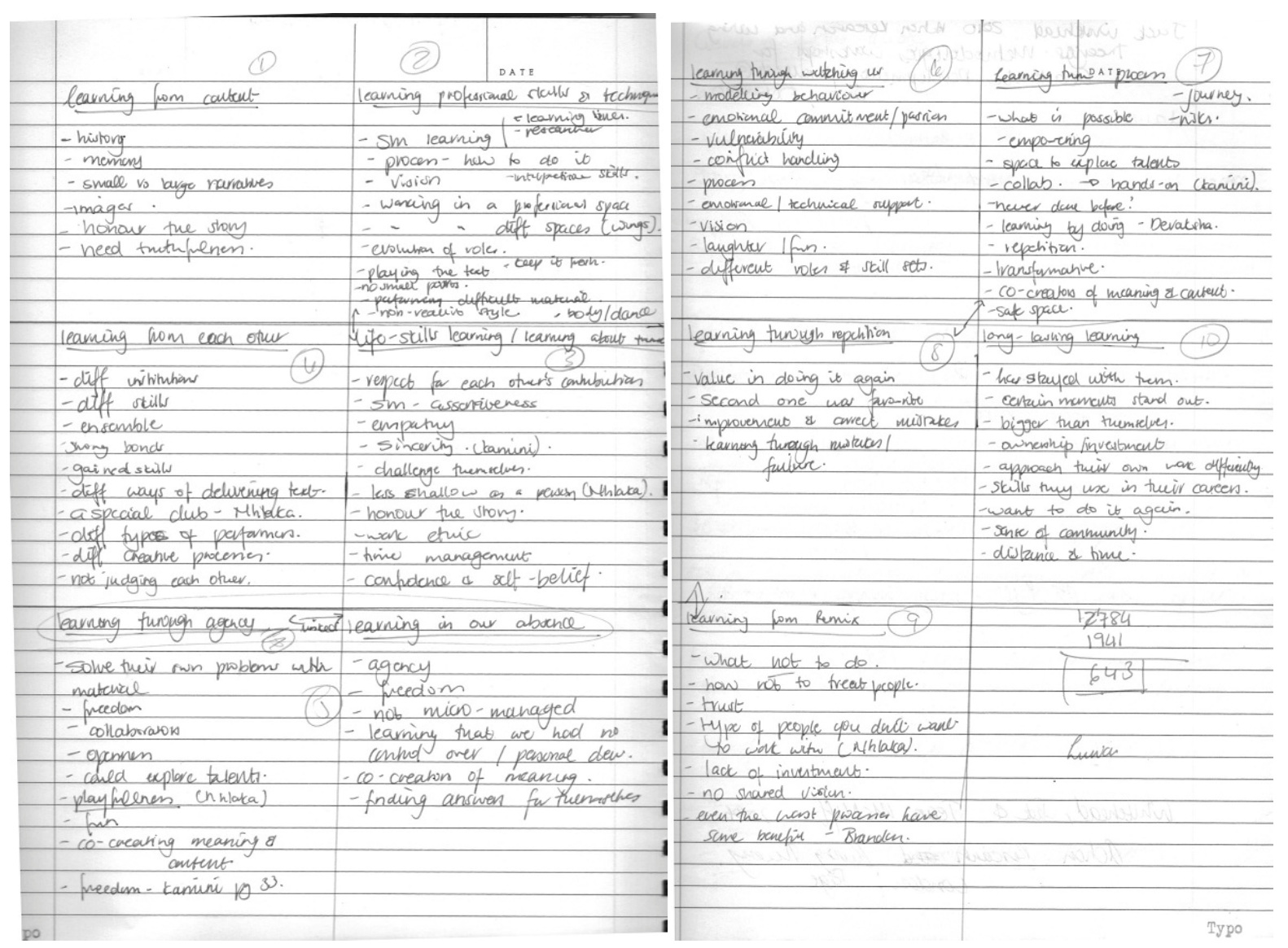

Figure 13: Grid-style visual map of the categories of teaching and learning evident in my collaborative theatre-making practice

Once I had done this, I was able to identify a number of categories or types of teaching and learning that I could then explore in greater detail. These included teaching and learning through content, through agency and independence, by watching each other and from each other, through process, through repetition (and by getting it wrong), as well as teaching and learning professional skills, performance techniques, and life skills. The final category dealt with the lasting teaching and learning that was the legacy of the project.

\section{Meaning making through visual mapping}

These examples illustrate how visual mapping of concepts and ideas informed the construction of meaning in my study as my thinking developed. This method of visual representation, and the fact that I chose to include it in my writing, falls within the ambit of self-study of practice research, as explained by Anastasia Samaras:

Arts-based self-study researchers use a wide range of art forms to represent and reinterpret, construct, and deconstruct meaning, and communicate their study of researching as they make it public. It can take many forms including visual/imagebased arts, for example, portraits, performance, photography, video documentary, art installations, multimedia representations, films, drawings, cartoons, graffiti, signs, cyber graphics, and diagrams. (2010, p. 722) 
Samaras also connected the use of such arts-based methods to the construction of knowledge "based in Vygotskian thought" (2010, p. 734), while Holbrook Mahn and Manuel F. AguilarTamayo have connected Vygotskian theories of concept formation to the theories of concept mapping (2010). These ideas conformed with the thrust of my study, which made use of Vygotskian notions to examine the processes of learning implicit in my collaborative theatremaking practice. Thus, the inclusion of my artefacts of thinking allowed me to infuse both self-study of practice methodologies and Vygotskian thought into the very fabric of my writing.

\section{Visual mapping as visible validity}

One of the most important critiques of the self-study of practice methodology concerns the notion of validity; the question is how researchers can separate themselves from the research when they are both researcher and the researched other. Alan Feldman articulated this concern, saying:

Issues of validity are important because when we engage in reflective processes that focus on ourselves (as in the construction of autobiographical narratives), we cannot be sure of the accuracy of what we see. That is because when we reflect, we do not know if what we see in the mirror is accurate or the distorted view provided by a funhouse mirror. Our new knowledge, understanding, or insight may be flawed because it is based on a distortion of the world. (2003, p. 27)

Thus, the challenge for self-study of practice researchers is to find ways to prevent the distortion of their view of the self-in-action through a rigorous, transparent, dialogic research process. There is no way for self-study researchers to be objective in their approach; rather, we can understand objectivity as "a chimera: a mythical creature that never existed, save in the imaginations of those who believe that knowing can be separated from the knower" (Guba \& Lincoln, 2005, p. 208). Therefore, as in all self-reflexive research, I assert the "authority of experience" (Pinnegar \& Hamilton, 2010, p. 153) and rely on my subjective, "felt knowledge" (Miller, 2016, p. 143).

Instead of objective "truth" as a standard of value for research, I, like many self-study researchers, understand validity in Guba and Lincoln's terms of being "authentic, trustworthy, rigorous" (2005, p. 207), and in terms of Mischler's notion of validation as "the process(es) through which we make claims for and evaluate the 'trustworthiness' of reported observations, interpretations, and generalizations" (1990, p. 418). Validity in self-study of practice is achieved through meticulous detailing of the processes used to generate data and analysis, and a transparent "open, honest and clear description of the spiral of questioning, framing, revisiting of data, and reframing of researcher's interpretations" (Samaras, 2011, p. 11). Visual mapping was one of the methods I used to demonstrate what Mishler called "the visibility of the work" (1990, p. 429). In this way, I was able to make plain the ways in which my thinking developed, and the connections I had made between theory, data, and analysis. 
By making my thinking process visible, I was able to allow my readers to "see the study and the links and leaps made" (Pinnegar \& Hamilton, 2010, p. 150).

\section{In conclusion}

An important part of my study was making the thinking in my practice and the thinking about my practice visible, both through the critical questions themselves and the ways in which I chose to answer them. In so doing, I was able to construct what Mishler called an exemplar, in which "theory and analysis are in a continuing dialectic with each other and with the data, and the process is open to us" (1990, p. 438). By making my methods and my meaningmaking open to the reader through the use of visual mapping, I was able to fulfil Mishler's demand for "articulating and clarifying the features and methods of our studies, of showing how the work is done and what problems become accessible to study" (1990, p. 423). In paying close attention not only to the what and the why of my research, but also to the how of my study, I engaged with Mishler's notion that "learning from exemplars is a process of contextually grounded practice" (1990, p. 437). Thus, despite the fact that the findings of my study may not be generalisable, being too closely bound to the context of my own work, the way in which I set out to find the answers in my study may help to point other self-reflexive researchers to methods and means for answering questions about their own work.

A great deal of the way in which I handled validity in my study was through the process of making my thinking about my doing, and my thinking about my thinking, visible through the process of visual mapping. Accordingly, I engaged in a metacognitive, self-reflexive process of examining my thinking and building an "awareness of and knowledge about [my] own cognition” (Krathwohl, 2002, p. 214). In Krathwohl's (2002) A Revision of Bloom's Taxonomy, the highest level of the knowledge dimension is metacognitive knowledge, which implies "Strategic Knowledge; Knowledge about cognitive tasks, including appropriate contextual and conditional knowledge; and Self-Knowledge" (p. 214). This implies that knowledge about thinking and about the self lie at the crux of this meta-level of knowing.

In thinking about my practice, and in carefully mapping my process of coming to know through my study, I made public the metacognitive and deeply embodied ways of knowing that my practice entails. In so doing, I embraced Dwight Conquergood's notion of knowledge that lies "betwixt and between theory and theatricality, paradigms and practices, critical reflection and creative accomplishment" (2002, p. 151). This allowed me to consider myself as both a knower of practice, and a knower about that knowing itself, as I sought to uncover my practice through the use of self-reflexive and visual research methods.

\section{References}

Bennis, W., \& Biederman, P. W. (1997). Organizing genius: The secrets of creative collaboration. Cambridge, MA: Perseus Books. 
Bolton, G. (2010). Reflective practice: Writing and professional development (3rd ed.). London, UK: SAGE.

Butler-Kisber, L., \& Poldma, T. (2010). The power of visual approaches in qualitative enquiry: The use of collage making and concept mapping in experiential research. Journal of Research Practice, 6(2), Art. M18. Retrieved from http://jrp.icaap.org/index.php/jrp/article/view/197/196

Buzan, T. (2010). Use your head: How to unleash the power of your mind. Cape Town, RSA: Prentice Hall.

Conquergood, D. (2002). Performance studies: Interventions and radical research. The Drama Review, 46(2), 145-156.

Eisner, E. (1997). The promise and perils of alternate forms of data representation. Educational Researcher, 26(6), 4-10.

Feldman, A. (2003). Validity and quality in self-study. Educational Researcher, 32(3), 2628.

Guba, E. G., \& Lincoln, Y. S. (2005). Paradigmatic controversies, contradictions, and emerging confluences. In N. K. Denzin \& Y. S. Lincoln (Eds.), The SAGE handbook of qualitative research (3rd ed.). Thousand Oaks, CA: SAGE.

John-Steiner, V. (2000). Creative collaboration. Oxford, UK: Oxford University Press.

Krasnic, T. (2010, August 23). Visual mapping: Connecting teachers with learning. The Southeast Education Network (SEEN). Retrieved from https://www.seenmagazine.us/Articles/Article-Detail/ArticleId/840/Visual-mapping

Krathwohl, D. R. (2002). A revision of Bloom's taxonomy: An overview. Theory into Practice, 41(4), 212-218.

LaBoskey, V. K. (2004). The methodology of self-study and its theoretical underpinnings. In J. J. Loughran, M. L. Hamilton, V. K. LaBoskey, \& T. Russell (Eds.), International handbook of self-study of teaching and teacher education practices (pp. 817-869). Dordrecht, NL: Springer.

Loughran, J. J. (2004). A history and context of self-study of teaching and teacher education practices. In J. J. Loughran, M. L. Hamilton, V. K. LaBoskey, \& T. Russell (Eds.), International handbook of self-study of teaching and teacher educatoin practices (pp. 7-39). Dordrecht, NL: Springer.

Mahn, H., \& Aguilar-Tamayo, M. F. (2010). Collaborative building of sociocultural and concept mapping theories [Paper presentation]. Fourth International Conference on Concept Mapping. Viña del Mar, Chile. http://cmc.ihmc.us/cmc2010Papers/cmc2010a2.pdf 
Meskin, T., \& van der Walt, T. (2018). Knowing in our bones: Interrogating embodied practice in theatre-making/theatre-teaching through self study. South African Theatre Journal, 31(1), 36-57.

Miller, A. (2016). Collected essays of Arthur Miller. London, UK: Bloomsbury.

Mishler, E. G. (1990). Validation in inquiry-guided research: The role of exemplars in narrative studies. Harvard Educational Review, 60(4), 415-442.

Mouton, J. (2001). How to succeed in your master's and doctoral studies: A South African guide and resource book. Pretoria, RSA: van Schaik.

Ovens, A., \& Fletcher, T. (2014). Doing self-study: The art of turning inquiry on yourself. In A. Ovens \& T. Fletcher (Eds.), Self study in physical education teacher education: Exploring the interplay of practice and scholarship (pp. 3-14). Dordrecht, NL: Springer.

Pinnegar, S., \& Hamilton, M. L. (2010). Self-study of practice as a genre of qualitative research. Dordrecht, NL: Springer.

Pithouse-Morgan, K., Mitchell, C., \& Pillay, D. (2014). Editorial. Educational Research for Social Change, 3(2), 1-4.

Polanyi, M. (1967). The tacit dimension. London, UK: Routledge \& Kegan Paul.

Richardson, L., \& St. Pierre, E. A. (2005). Writing: A method of inquiry. In N. K. Denzin \& Y. S. Lincoln (Eds.), The SAGE handbook of qualitative research (pp. 959-978). Thousand Oaks, CA: SAGE.

Samaras, A. P. (2010). Explorations in using arts-based self-study methods. International Journal of Qualitative Studies in Education, 23(6), 719-739.

Samaras, A. P. (2011). Self-study teacher research: Improving your practice through collaborative inquiry. Los Angeles, CA: SAGE.

Sawyer, R. K. (2003). Group creativity: Music, theatre, collaboration. Mahwah, NJ: Lawrence Erlbaum.

van der Walt, T. (2018). Co-directing, co-creating, collaborating: A self-reflexive study of my collaborative theatre-making practice [Unpublished doctoral dissertation]. University of KwaZulu-Natal.

Weber, S. (2014). Arts-based self-study: Documenting the ripple effect. Perspectives in Education, 32(2), 8-20.

Whitehead, J., \& McNiff, J. (2006). Action research: Living theory. London, UK: SAGE. 